\title{
C02 Huff-n-Puff Process in a Light Oil Shallow Shelf Carbonate Reservoir
}

\author{
Quarterly Report \\ October 1 - December 31, 1997
}

\author{
By: \\ Scott Wehner; Mark Kovar
}

Work Performed Under Contract No.: DE-FC22-94BC14986

\author{
For \\ U.S. Department of Energy \\ Office of Fossil Energy \\ Federal Energy Technology Center \\ P.O. Box 880 \\ Morgantown, West Virginia 26507-0880
}

By

Texaco Exploration \& Production Inc.

P. O. Box 3109

Midland, Texas 79702 


\section{Disclaimer}

This report was prepared as an account of work sponsored by an agency of the United States Government. Neither the United States Government nor any agency thereof, nor any of their employees, makes any warranty, express or implied, or assumes any legal liability or responsibility for the accuracy, completeness, or usefulness of any information, apparatus, product, or process disclosed, or represents that its use would not infringe privately owned rights. Reference herein to any specific commercial product, process, or service by trade

name, trademark, manufacturer, or otherwise does not necessarily constitute or imply its endorsement, recommendation, or favoring by the United States Government or any agency thereof. The views and opinions of authors expressed herein do not necessarily state or reflect those of the United States Government or any agency thereof. 


\section{$\mathrm{CO}_{2}$ HUFF-n-PUFF PROCESS \\ IN A LIGHT OIL \\ SHALLOW SHELF CARBONATE RESERVOIR}

(No. DE-FC22-94BC14986--20)

\section{QUARTERLY TECHNICAL PROGRESS REPORT}

Texaco Exploration \& Production Inc.

P.O. Box 3109

Midland, TX 79702

Date of Report:

Award Date:

Anticipated Completion Date:

DOE Obligation/Award (current year):

Program Manager:

Principal Investigator(s):

Contracting Officer's Representative (COR):

Reporting Period:
$1-31-98$

02-10-94

$12-31-97$

$\$ 345,778.00$

Scott C. Wehner

Scott Wehner

Mark Kovar

Jerry Casteel / BPO

4th Qtr. 1997 


\section{LEGAL NOTICE/DISCLAIMER}

This report was prepared by Texaco Exploration and Production Inc. (TEPI) pursuant to a Cooperative Agreement partially funded by the U. S. Department of Energy (DOE), and neither TEPI nor any of its subcontractors nor the DOE, nor any person acting on behalf of either:

(A) Makes any warranty or representation, express or implied, with respect to the accuracy, completeness, or usefulness of the information contained in this report, or that the use of any information, apparatus, method, or process disclosed in this report may not infringe privatelyowned rights; or

(B) Assumes any liabilities with respect to the use of, or for damages resulting from the use of, any information, apparatus, method or process disclosed in this report.

References herein to any specific commercial product, process, or service by trade name, trademark, manufacturer, or otherwise, does not necessarily constitute or imply its endorsement, recommendation, or favoring by the DOE. The views and opinions of authors expressed herein do not necessarily state or reflect those of the DOE. 


\section{OBJECTIVES}

The principal objective of this $\mathrm{CO}_{2}$ Huff-n-Puff $(\mathrm{H}-\mathrm{n}-\mathrm{P})$ project is to determine the feasibility and practicality of the technology in a waterflooded shallow shelf carbonate environment. The results of parametric simulation of the $\mathrm{CO}_{2} \mathrm{H}-\mathrm{n}-\mathrm{P}$ process, coupled with reservoir characterization components are to be used to determine if this process is technically and economically feasible for field implementation. The technology transfer objective of the project is to disseminate the knowledge gained through an innovative plan in support of the Department of Energy's (DOE) objective of increasing domestic oil production and deferring the abandonment of shallow shelf carbonate (SSC) reservoirs. Tasks associated with this objective are carried out in what is considered a timely effort for near-term goals.

\section{BACKGROUND}

Texaco Exploration and Production Inc. (TEPI) has mid-term plans to implement full-scale miscible $\mathrm{CO}_{2}$ projects in the Permian Basin of West Texas and Southeast New Mexico. The economic market precludes acceleration of such capital-intensive projects in many cases. This is a common finding throughout the Permian Basin SSC reservoirs. In theory, it is believed that the "immiscible" $\mathrm{CO}_{2} \mathrm{H}$-n-P process might bridge these longer-term "miscible" projects with nearterm results. A successful implementation would result in near-term production, or revenue, to help offset cash outlays during the initial startup of a miscible flood. The DOE partnership provides some relief to the associated R \& D risks, allowing TEPI to evaluate a proven Gulfcoast sandstone technology in a waterflooded carbonate environment. Numerous sites exist for widespread replication of this technology following a successful field demonstration.

TEPI concluded all of the Tasks associated with the First Budget Period by October 1995. The DOE approved the TEPI continuation application. Budget Period No. 2 concluded with year-end 1997. Initial injection of $\mathrm{CO}_{2}$ at the first demonstration site, Central Vacuum Unit (CVU) began in November 1995, and after a short shut-in period for the soak, the first demonstration site was returned to production in late December 1995. Monitoring the results of the first demonstration site continued through mid-year 1996. The $\mathrm{CO}_{2}$ Huff-n-Puff process did not meet with successful results at the CVU test site. There are several reasons contemplated as to the reasons behind the results. Most notable is that it was discovered in the simulation studies that the establishment of a high residual or trapped $\mathrm{CO}_{2}$ saturation was necessary for a Huff-n-Puff to recover incremental oil in an ongoing waterflood. A trapped $\mathrm{CO}_{2}$ saturation prevents oil from resaturating a reservoir volume from which the oil had been previously recovered. Without trapped $\mathrm{CO}_{2}$, the affected reservoir volume would be resaturated by oil and restored to about the same saturations present before the Huff-n-Puff. Incremental oil would not be recovered, and it would be as if the Huff-nPuff never happened. There is evidence that the Vacuum Field reservoir may not be amenable to the required trapping of $\mathrm{CO}_{2}$ gas in the matrix. Near-wellbore gas trapping of $\mathrm{CO}_{2}$ has been cited as one possible cause of reduced injectivity following Water-Alternating-Gas (WAG) injection methods employed in many miscible $\mathrm{CO}_{2}$ floods. Since the Vacuum Field reservoir does not experience water injectivity reduction, it may not be amenable to trapping of $\mathrm{CO}_{2}$ gas in the matrix. However, other reservoirs, which have experienced injectivity reduction during the water cycle in a WAG process, may be much better candidates. The water injectivity reduction may 
indicate the presence of a trapped $\mathrm{CO}_{2}$ saturation. The Slaughter Sundown Unit (SSU) is just such a reservoir.

A second demonstration site was chosen at TEPI's SSU. Initial injection at this site commenced in June 1997. After a three-week soak period, the well was put on production in August 1997. This report reviews performance from the second demonstration site where the project has recently been completed.

\section{SUMMARY of TECHNICAL PROGRESS}

\section{FIELD DEMONSTRATION: SSU}

Results. The Third Quarter 1997 Technical Progress Report gave a brief field description and history of the Sundown Slaughter Unit. The criteria used to select a candidate well was also discussed. The reader is referred to the earlier report for this information. A detailed description of the injection, injection and production surveys, and production through September 30, 1997 was also given in that Report. An abbreviated version of that will be repeated here to provide background for current production results through December 31, 1997.

$\mathrm{CO}_{2}$ injection for the SSU demonstration site began on June 16, 1997 in well No. 1341. On July 10,1997 , an injection profile was acquired in order to determine which zones were taking $\mathrm{CO}_{2}$. Notably, $27 \%$ of the fluid apparently exited the casing below all of the perforations, i.e. through the casing shoe. $\mathrm{CO}_{2}$ injection continued through August 6, 1997 (51 days) with a total of 34 MMscf being injected into the demonstration site. The well was shut in for a three-week soak period, then returned to production on August 26, 1997. Initial production was $100 \% \mathrm{CO}_{2}$. The first oil appeared on September 4, 1997 (on the 7th day of production) when the well flowed 5 BOPD and 16 BWPD. Pressure upstream of the choke had decreased from 1,500 psig to 1,100 psig during this time while flowing on an 8/64" choke. Oil production fluctuated between zero and 23 BOPD, while water production ranged from 0 BWPD to 26 BWPD on 8/64", 9/64", and 10/64" chokes until September 20, 1997. On September 21, the choke was opened to 16/64" with a flowing tubing pressure of 850 psig. Production jumped to 53 BOPD and 87 BWPD. The well was choked back the next day to $12 / 64$ " due to freezing problems in the choke. On September 26 a production profile log was run to determine which zones were contributing fluid. No oil or gas was produced from below the perforations (i.e. the casing shoe). Four percent of the water apparently was being produced from below the casing shoe. On September 28, the choke was opened up permanently to 45/64", and production for the next three days was 334 , 196 , and 128 BOPD, respectively, before dropping back to 22 BOPD on the fourth day. It should be noted here that the high tests of 334, 196, and 128 are somewhat questionable based on findings later on in the test period, which will be discussed shortly. Production then fluctuated between 0 BOPD and 23 BOPD until October 25, when a pumping unit was installed. Flowing tubing pressure had decreased to $50 \mathrm{psig}$ by that time. The first two tests after the pumping unit installation were 90 and 263 BOPD respectively. At this time it was discovered that there was a problem with the test facilities. The well was being tested through a test separator at the SSU battery. This test separator is the same one used to gage all other wells in that part of the field, so there was a high confidence level of getting accurate tests. However, it was discovered that the micromotion sensor was interpreting gas laden fluid (oil + water + gas) as a high oil cut fluid, 
hence the high oil production reported. It is suspected, but not proven, that the same thing may have happened on September 28 when we had three days of extraordinarily high tests. Unfortunately we can not quantify the degree of error, if any, in the tests. Based on simulation and actual results from CVU, increased liquid rates are to be expected when higher gas rates occur so we probably did get some increase in oil and total fluid production. We believe that when the back pressure on the formation was decreased drastically, we experienced an extraordinary influx of gas which may have adversely affected the test facilities. On September 28 we opened the choke from 13/64" to $30 / 64$ ", then to $45 / 64$ " in a matter of two days. Previous choke size increases were only in $1 / 64$ " or $2 / 64$ " increments. This sudden increase in choke size resulted in a decreased flowing tubing pressure, from 725 psig to 100 psig. Likewise, when we installed the pumping unit, much of the hydrostatic head on the formation was removed, allowing for another influx of gas resulting in another two days of very high tests. By the end of December, production had returned to pre-Huff-n-Puff levels of about 2 BOPD. Cumulative oil production as of December 31, 1997 was 1786 STB. Even though some of the tests are suspect, for lack of better information, this volume will be assumed the best case scenario for economic purposes.

It is obvious that some incremental production was recovered from this demonstration site. Had the well not been exposed to the process, production from June 16 through December 31, 1997 (199 days) would have been about 398 STB. It appears that we recovered about 1388 STB of incremental oil. Although, as previously discussed, this recovery may be an optimistic scenario.

\section{ECONOMICS}

The actual project costs associated with the second field demonstration components are included in Table 1.

Table 1: Field Demonstration Costs

$(\$ \mathrm{M})$

\begin{tabular}{|c|c|}
\hline DEMONSTRATION & Direct Cost (M\$) \\
\hline Materials-Line Pipe, valves, fittings & 6 \\
Labor-Install flowline \& Misc Surface Cost & 6.1 \\
Trucking-Pump \& Transport & 8.5 \\
CO2 Commodity & 23 \\
Wireline & 3.5 \\
Service Unit \& Misc Downhole & 13.7 \\
In-Line Heater \& Propane & 3.5 \\
Downhole pump \& Parts & 6.6 \\
Misc. & 6 \\
TOTAL: & $\underline{76.9}$ \\
DOE Share (45\%) & 34.6 \\
CVU Share (55\%) & 42.3 \\
\hline
\end{tabular}


Table 2 shows some simple relationships depicting the basic economics of the H-n-P demonstration at SSU. Assuming an $\$ 18.00 /$ STB sales price for crude oil, the necessary volume of recovery to reach a pseudo-breakeven point is calculated to be $4272 \mathrm{STB}$ of oil. This recovery results in a breakeven $\mathrm{CO}_{2}$ utilization efficiency of $8.0 \mathrm{Mscf}$ of $\mathrm{CO}_{2}$ injected per barrel of oil recovery as compared to CVU which had a breakeven efficiency of $3.2 \mathrm{Mscf} / \mathrm{STB}$. The higher (better) breakeven point at SSU is the result of lower costs, particularly regarding the cost of $\mathrm{CO}_{2}$. The $\mathrm{CO}_{2}$ at $\mathrm{CVU}$ was trucked to the site and pumped at a cost of $\$ 2.85 / \mathrm{Mscf}$. The availability of pipeline $\mathrm{CO}_{2}$ at SSU resulted in a substantial cost savings since the $\mathrm{CO}_{2}$ costs only $\$ 0.679 /$ Mscf.

\section{Table 2: Field Demonstration Economics}

\begin{tabular}{|c|c|c|}
\hline DEMONSTRATION & $\begin{array}{r}\text { CVU } \\
\text { ACTUAL }\end{array}$ & $\begin{array}{c}\text { SSU } \\
\text { ACTUAL }\end{array}$ \\
\hline CO2 Vol., MMscf & 50 & 34 \\
CO2 Cost, \$/Mscf & 2.85 & 0.679 \\
Deferred Production, STB & & \\
TOTAL Cost, \$M & 2924 & 398 \\
Equiv. Bbl's @ \$18/STB & 284.1 & 76.9 \\
Breakeven Utilization, Mcf/STB & 15800 & 4272 \\
\hline
\end{tabular}

As can be seen, the SSU demonstration site, like that of the previous demonstration at CVU, failed to produced sufficient quantities of oil to reach the breakeven point. Therefore, without much probability of a successful demonstration, the project is being terminated as originally scheduled; although short of the originally planned number of demonstrations.

Additional benefits that are not accounted for in this simplistic review include reduced electrical requirements during the injection, soak and flow period and reduced water handling requirements for an extended period of time.

\section{CONCLUSIONS}

A successful demonstration of the $\mathrm{CO}_{2}$ Huff-n-Puff process could have had wide application. The proposed technology promised several advantages. It was hoped that the $\mathrm{CO}_{2}$ Huff-n-Puff process 
might bridge near-term needs of maintaining the large domestic resource base of the Permian Basin until the mid-term economic conditions supported the implementation of more efficient, and prolific, full-scale miscible $\mathrm{CO}_{2}$ projects. Although it still has promise for other, pressure depleted reservoirs, the Huff-n-Puff process does not appear to be viable at CVU or SSU, both waterflooded SSC type reservoirs.

The field demonstration at SSU did exhibit a large trapped gas saturation. As of December 31, 1997 only $30 \%$ of the injected gas had been recovered. The well is currently producing about 30 Mscf/D which includes $87 \% \mathrm{CO}_{2}$. The gas rate has been declining throughout the test period and is trending toward its' pre-test gas rate of $2 \mathrm{Mscf} / \mathrm{D}$. It is obvious that a large amount of $\mathrm{CO}_{2}$ will remain trapped in the formation. Unlike CVU, incremental oil was recovered in the test at SSU. Unfortunately, incremental recovery was not sufficient to pay for the costs of the test. As previously speculated, recovery performance may be a function of pore size, pore throat configuration, fluid saturations and fluid composition, as well perhaps some other unknown phenomena.

It is interesting to note that near-wellbore gas trapping of $\mathrm{CO}_{2}$ has been cited as one possible cause of reduced injectivity following Water-Alternating-Gas (WAG) injection methods employed in many miscible $\mathrm{CO}_{2}$ floods. Although SSU did exhibit gas trapping, incremental recovery was so low that further tests at SSU are not warranted. The Huff-n-Puff technology might become a valuable indicator of potential injection rates when designing a miscible $\mathrm{CO}_{2}$ flood. Injectivity is one of the main parameters affecting the economics of these large-scale miscible projects. The failure of the Huff-n-Puff might indicate favorable expectations of injection, whereas a positive response may suggest injectivity reductions-thus, possibly the option for parallel implementation of the Huff-n-Puff technology on a limited basis. Although the process was not successful at returning profitable oil volumes, it did have an impact of production of water. This could be an area for further study, since the expenses associated with lifting water, and it's disposal, impact operators profits considerably.

In addition to requirements for a trapped gas saturation, there appears a "rate" requirement for a successful H-n-P which may not be possible due to disposal limitations at SSU. The downsteam line pressure at SSU was mechanically limited at about $50 \mathrm{psig}$, resulting in gas production rates of less than $400 \mathrm{Mscf} / \mathrm{D}$. As the flowing tubing pressure decreased, the choke was gradually opened up but the gas rate was continuously and artificially restricted by the choke. As a result, the maximum flow rates, based on simulations at CVU that would yield the greatest recovery were never realized. The total liquid production from the well also decreased during the period when the gas production was reduced. Modifications of the history match at CVU as well as previous parametric simulations indicate that increasing the gas production rate will also increase the total liquid production rate, which, in turn, will increase the incremental oil. If the total liquid production rate during the Huff-n-Puff cannot be maintained at the same level (or at least a high fraction) of the pre-Huff-n-Puff level, then the Huff-n-Puff will not be successful because the oil rate will be too small (even though the oil-cut might be improved). In the case of SSU, pre-test total liquid rates were about 400 BFPD. During the first month of testing, rates varied from 0 to about 50 BFPD. On September 27 the choke was opened up to its' fullest potential but back pressure remained on the formation, and by this time flowing tubing pressure had declined 
substantially. Even with a wide-open choke, flow rates remained below pre-test levels. If the test wells at CVU and SSU are typical, a successful Huff-n-Puff may not be possible for a well which must be converted from pumping status to flowing status and back again. The liquid production rate during the flowing period would simply be too low. This work suggests that improved oil production rates may be possible if higher gas volume production equipment can be utilized.

Huff n' Puff response at SSU is much better than at CVU in that incremental recovery was obtained. The reason for the improved response may be that the hypothesis of a difference in the trapped $\mathrm{CO}_{2}$ saturation between the SSU reservoir and the CVU reservoir may be correct. It was hypothesized that the CVU did not have a high trapped $\mathrm{CO}_{2}$ saturation because of the poor Huffn-Puff response. It was further supported by the absence of water injectivity loss in the comparable East Vacuum Grayburg San Andres Unit miscible WAG operations to the east of $\mathrm{CVU}$. The SSU was hypothesized to have a high trapped $\mathrm{CO}_{2}$ saturation because of water injectivity loss during WAG operations in the miscibly flooded Eastern part of the field.

The Vacuum Huff-n-Puff had no incremental oil at all during the flowing phase and experienced its highest oil rates a few days after the Huff-n-Puff well was placed back on pumping status. Further evidence of a higher trapped $\mathrm{CO}_{2}$ saturation in the Slaughter reservoir is that only $23 \%$ of the injected $\mathrm{CO}_{2}$ was recovered before the Huff-n-Puff well was returned to pumping status while 39\% had been recovered when the CVU Huff-n-Puff well was returned to pumping status. Essentially all of the injected $\mathrm{CO}_{2}$ was ultimately produced in the Vacuum project. Whereas, the majority of $\mathrm{CO}_{2}$ in the SSU demonstration may never be produced.

At this point it appears that the test met with limited success but was an economic failure. Approximately 4300 barrels of incremental oil, i.e. oil over and above what would have been produced under normal operations, would be required to pay out the project. Actual incremental recovery was just 1388 barrels of oil. Unfortunately, the volumes of recovery do not appear attractive. Additionally, operational problems will continue to be a hurdle that these demonstration sites and other leases must deal with, particularly the inability to produce the wells at maximum rates due to equipment restrictions.

\section{REFERENCES/PUBLICATIONS}

The Petroleum Recovery Research Center continues to provide updates on the project in its quarterly newsletter. In addition, the Petroleum Technology Transfer Counsel, a joint venture between the Independent Producers Association of America (IPAA) and DOE is providing complete quarterly and annual Technical Reports on an Industry Bulletin Board on the internet called GO-TECH. This is allowing a more timely dissemination of information to interested parties following the progress of the project. 